\title{
Incentives Factors for the Performance of Microfinance Institutions in Cameroon
}

\author{
Djontu Maurice Armand ${ }^{1 *}$, Nguejio Tsajio Germain ${ }^{2}$
}

\begin{abstract}
${ }^{1}$ Doctor/PhD in Management Sciences, Accounting-Finance Department, Faculty of Economics and Management Sciences, Laboratory of Research in Management (LAREMA), University of Dschang-Cameroon

${ }^{2} \mathrm{Ph}$. D Student in Management Sciences, Accounting-Finance Department, Faculty of Economics and Management Sciences, Laboratory of Research in Management (LAREMA), University of Dschang-Cameroon
\end{abstract}

DOI: $10.36347 /$ sjebm.2021.v08i02.002

| Received: 17.01.2021 | Accepted: 01.02.2021 | Published: 09.02.2021

*Corresponding author: Djontu Maurice Armand

\section{Abstract}

The objective of this study is to identify the Cameroon Microfinance Institutions performance determinants. We then apply the non-parametric method DEA and the censured Tobit model on a sample of 106 Microfinance institutions (MFI) in Cameroon. The DEA model permitted us to appraise the IMF efficiency levels whereas the censured Tobit model enabled us to identify the factors influencing the performance of the considered MFI. The DEA model therefore shows that the Cameroon MFI is technically performant. However, among the factors influencing performance, we found that the size of the board of directors, the number of clients, and the location of the organization exert a positive and significant influence on the performance, while the risk portfolio exerts an influence negative but significant on it. This study higlights factors that explain the performance of microfinance institutions.

Keywords: Microfinance; Performance; censored Tobit; determinants; DEA.

Copyright $(\mathcal{C} 2021$ The Author(s): This is an open-access article distributed under the terms of the Creative Commons Attribution 4.0 International License (CC BY-NC 4.0) which permits unrestricted use, distribution, and reproduction in any medium for non-commercial use provided the original author and source are credited.

\section{INTRODUCTION}

In Cameroon, as everywhere else in developing countries, access to financial resources is the main constraint to the development of micro and small enterprises (MSEs) and an important blocking factor for their growth. Thus, a large section of the population, which despite its entrepreneurial spirit, does not find access to the financial means necessary for the creation or development of any income-generating activity. This population is excluded by commercial banks. The main reasons for this are the imperfections of the credit market, on one hand, and the fact that poor people lack assets to present as collateral when applying for credit. Microfinance, through microcredit, has come to fill the funding gap for micro-enterprises boycotted by traditional financial systems.

Since their appearance in Cameroon, in the aftermath of independence, microfinance institutions have grown exponentially to the point that as of December 31, 2014 (Finance Law, 2015), the resources available in Cameroon MFIs are rising to nearly 519 billion CFA F against 258 billion on $31^{\text {st }}$ December 2008. The dynamism of this sector has made it possible to have more than one million people who benefited from microfinance services in 2014 in Cameroon (finance law, 2015). The micro-finance sector returned to positive results in 2014. After the successive losses of 4.4 billion in 2013, 1.9 billion in 2012, 3.7 billion in 2011 and 5.567 billion in 2008, its overall net income is 195 million. This improvement is due to the consolidation of the portfolios of some MFIs, including the reduction in deficit recorded by the First Trust Savings and Loans.

In addition, despite the increase in the volume of deposits and the amount of credit granted by MFIs, their intermediation activity faces two major difficulties. First, the portfolio quality of MFIs has deteriorated. Doubtful accounts represent more than a quarter of out standings granted to customers in 2008. In the second place, the micro-finance sector produced the same year an aggregate deficit of CFAF 5.567 billion [1]. The above-mentioned difficulties highlight the question of the financial profitability and even the sustainability of MFIs. Also, the interest rates charged remain high. Indeed, the average lending and creditor rates are $21 \%$ and $4 \%$ for an average intermediation margin of $17 \%$ [Kobou, et al. [2], Mondjeli [3]. The high cost of interest rates leads to the exclusion of a portion of the original target population of MFIs 
creating a "creditcrowdingeffec $\left[{ }^{1}\right] \mathrm{t}$ ". Nzongang and Kamdem [4] show that, according to the intermediation approach, the efficiency scores are very low; but also a preponderance of decreasing yields. This suggests inefficient management of credit deposit processing, which is consistent with Kobou, and al. [2] the low coefficient of transformation of savings collected in credit. In sum, institutions effectively collect resources but are less efficient in granting credit and achieving social goals.

What emerges from the evolution of microfinance in Cameroon is that, despite its emergence and relative development, the question of performance remains crucial. The performance of a microfinance institution assumes that the microfinance institution uses the minimum of resources for maximum production [4]. Indeed, an MFI that manages the resources it has at its disposal could easily improve the quality of its portfolio $\left[^{2}\right]$ as well as that of its result; hence our interest in studying the factors of the performance of microfinance institutions in Cameroon. This issue of factors of performance of MFIs has been the subject of scientific productions for a number of years.

Numerous studies have highlighted the factors that explain the performance of microfinance institutions. The results found are not all concordant. Below, we try to present the results of some recent articles.

By analyzing data from a sample of 124 MFIs from 49 countries over a period of time between 1999 and 2002, Cull, and al. [5] find that it is possible to achieve both objectives of microfinance: aggressively pursue commercial objectives without moving away from the social mission. The authors qualify their results by showing that the sub-sample of MFIs using the individual loan methodology achieves a higher average profit, but its performance in terms of scope is small compared to other MFIs. The results for larger and older MFIs show that as an institution grows and matures, it is increasingly focused on clients who can afford to apply for large loans.

Ejigu [6] finds a positive relationship between the average loan size and operational self-sufficiency, on one hand, and a negative relationship between the number of women among MFI clients and operational self-sufficiency, on the other hand. Since the average loan size variable and the number of women variable are indicators of the scope of an MFI, then the relationships found with operational self-sufficiency show that there is some trade-off between financial performance and the social performance of the MFIs in the case of Ethiopia. However, by analyzing a sample

${ }^{1}$ Excess liquidity of financial institutions

${ }^{2}$ Touch the maximum of poor people from the same country, Kereta [7] finds no evidence of a possible tradeoff between the two objectives, even though the results show a positive correlation between the two.

For its part, Hartarska [8] finds results that show, in the case of MFIs in Central Europe, Eastern Europe and the newly independent states, the presence of representatives of certain categories of stakeholders in the executive board can lead MFIs to arbitrate between scope and viability. Thus, the results show that the presence of representatives of donor in the board of directors has a positive impact on reach and a negative impact on sustainability. The opposite of its results is found when client representatives are present on the board of directors of microfinance institutions.

Bassem [9] finds a result almost similar to that of Kablan [10]. There is no scale economy for MFIs operating in the WAEMU zone. The training coefficient is negative, indicating that MFIs providing training and consulting with their clients incur higher costs. As a result, this ultimately has a negative impact on their effectiveness. Finally, as expected, subsidy and age have positive coefficients. The age of MFIs is an asset in the distribution of financial services, but also in the ability to reach the poorest segments of the population. Similarly, even grants help to improve the efficiency of MFIs.

Kablan [10] in his study on the effectiveness of microfinance institutions in WAEMU shows that the efficiency of MFIs is influenced by a number of factors (specific, financial management, environmental). It leads to the results according to which the profitability of MFIs positively impacts their efficiency. All the same, it appears from this study that size has a negative impact in CRS and VRS. Large MFIs would be less efficient than smaller ones.

Kobou and al [2], in their study of the effectiveness of financing micro and small enterprises in the fight against poverty in Cameroon, show, on a sample of 181 MFIs of the CAMCCUL network, that the performance or the underperformance of these MFIs would be attributable to a number of factors such as: the geographical area, the number of women members and the credit interest rate. In fact, they show that MFIs are moderately effective, but these results conceal disparities due to either socio-cultural factors (MFIs located in the English-speaking area are more effective than those in the Francophone zone), the percentage of women, or credit interest rates. Regarding this last aspect, the high credit rates suggest that the MFIs studied give privilege to profitability objectives to the detriment of their social purpose.

Jebli [11], conducts a study on the factors of performance of Moroccan microfinance institutions. Given a sample of ten (10) microfinance associations, 
the author shows that: the use of subsidies negatively affects financial performance; good control of the risk portfolio negatively affects social performance; all the same, he notes the existence of a positive link between financial performance and social performance.

Mondjeli [3], on his side, finds as factors of effectiveness levels, age, the number of women members of the MFI, the poverty rate, the debit interest rate and the region of implantation. Among these variables, the most important is the poverty rate because it is significant at $1 \%$ and has the highest coefficient. In addition, the marginal effects analysis reveals that an increase in the poverty rate of $1 \%$ would reduce the efficiency of MFIs by $1.63 \%$. Thus, reducing the poverty rate will increase the efficiency of MFIs, which in turn will be able to target the poor more and ultimately help reduce poverty. The second variable is the debtor interest rate, the decrease of which would lead to an improvement in the efficiency of MFIs. The practice of high debit interest rates by MFIs can be explained by the existence of information asymmetries in the lender-borrower relationship. In order to get MFIs to reverse this trend, one solution would be, for example, setting up a system of subsidies by the State because it is undeniable that their activities contribute to the achievement of the MDGs. Although having low significance, the number of women members of the MFI improves the efficiency of the latter. Age and region of implantation also explain the efficiency levels of MFIs.

In view of the above, we note that there are few studies analyzing the factors that explain the performance of MFIs in the Cameroonian context. In addition, all these works use the classical ratios in the calculation of the performance; with the exception of the work of Kobou, and al. [2] and of Mondjeli [3]. These shortcomings therefore form the basis of our study. The central question of this article is what are the factors that influence the performance of Cameroonian microfinance institutions?

In addition to the introduction, the article is structured around four axes. The first presents the review of the literature on the subject, the second presents the methodological approach used in the context of this research, and the third presents the empirical results of the research. We will end with the conclusion.

\section{Review of literature}

This review of the literature focuses first on the theoretical aspect, and secondly on empirical work highlighting the factors likely to significantly influence the efficiency of MFIs in the world in general and in Cameroon in particular.

\section{Theoretical aspect}

Several economic theories can help elucidate the performance of microfinance from the point of view of stakeholders, i.e. microfinance organizations and beneficiaries of their financial services. The analysis of the strengths and weaknesses of these theories will be based primarily on the assumption that an organization is only considered effective if there are no other organizations in which each person would in average obtain better results for all possible modes of operation [12].

The main objective of this point is to identify, through various theoretical trends that explain microfinance performance, the main indicators that can be used to assess the effectiveness of microfinance organizations in the MC2 network.

There are indeed several distortions (including credit rationing) between the lender and the borrower. These distortions are generally due to the information asymmetry and consequently the inefficient financial intermediation. In the credit relationship, the information appears asymmetrically distributed. It will be easy to see that the borrower has better information than the lender on the parameters that will determine the actual profitability of the project and then govern the revenue sharing [13]. Aware that the transaction may take place under conditions that are disadvantageous for him, the lender may have to ration credit. This approach presupposes the existence of allocative inefficiency, since risk is discriminated by prices [14].

Faced with this problem, microfinance proposes some so-called "innovative" mechanisms in order to preserve the effectiveness of financing.

The theory of financial repression offers a first approach to the effectiveness of microfinance organizations compared to traditional financial institutions. It explains the concept of productive efficiency, the persistence of credit rationing in microfinance. It originated in the work of McKinnon and Shaw [15]. Financial repression is manifested by a number of the restrictive measures that the public authorities impose on the exercise of financial activity in an economy. These restrictions essentially consist of: the administrative fixing of interest rates, the constitution of required reserve ratios, the regulation of competition, exchange control.

Of these various measures of financial repression, the deliberate policy of low interest rates practiced in most developing countries has been the subject of the largest debates. In most of these countries, governments, often through the central bank, apply a selective lending policy to the so-called priority sectors. To do this, they set debtor interest rates at a low level for the entire national economy. Strictly speaking, 
financial repression is thus manifested by the government's fixing of interest rates below the equilibrium level. When viewed from a cost perspective, an MFI's efficiency is broadly based on its ability to balance risk and return, to be covered in a market economy, by the differential between lending and deposit rates (gross margin), fund raising costs, loan management and recovery costs as well as the risk premium of the financial intermediary on the Soulama [16] microcredit operations. To prevent MFIs from being tempted to conceal their underperformance by increasing their lending interest rates, these rates can be regulated in the form of a threshold of attrition. This is often set slightly above the overall effective rates of the regulated institutions.

This theory is usefully complemented by the theory of transaction costs that enriches the analysis of productive efficiency and addresses complementary concepts such as economies of scale. To justify their role as an effective financing mechanism for microenterprises, MFIs must generate a lower total cost than the use of individual lenders. It is inconceivable that a financial system can be more economical than an individual lender in terms of transaction costs generated [17]. It is therefore necessary to propose financial costs that are sufficiently lower than those of the individual lenders in order to offset the additional cost that is generated in transaction costs. Thus, the productive efficiency of MFIs, that is, the profitability of their financial services to micro-enterprises will be proven. It should be noted that the emphasis is no longer put here on the need to impose on MFIs a possible rate of attrition to encourage them to be more efficient, or even competitive. The transaction cost theory suggests that the MFIs adopt a mode of organization that allows them to save on these costs. Given the strong specificity of microfinance assets, certain organizational modes such as internalization of activities or vertical integration can help reduce transaction costs and thus increase the productive efficiency of microfinance organizations. In practice, mergers can be used by some microfinance organizations to reduce their costs. It can also be the absorption of microfinance organizations by conventional banks or even mergers between these two types of organizations.

Finally, the theory of property rights, addressing the problem of divergence of interests between different stakeholders in microfinance, provides the basis for assessing the internal and external social sustainability of organizations from the perspective of good governance and therefore allocative efficiency. Property rights must be well defined, transferable and protected in order to ensure optimal allocation of resources. In the field of microfinance, this concept only applies to organizations that hold equity capital. Some NGOs, which do not have one, do not lend themselves to the type of analysis. As for the institutions whose capital belongs to the members or members (savings and credit cooperatives and mutual tontines), they are illustrated in terms of the alteration of property rights. Indeed, in these organizations, the transferability of issued titles (shares or interest shares) is not ensured while protection or exclusivity is mitigated. In reality, there is no transferability because a participant cannot freely sell his or her security (interest) in a market - the equivalent of a stock exchange - or otherwise dispose of it other than by express renunciation. With the organization (COOPEC or Tontines). Very often, it is the withdrawal of the member (and therefore of his interest shares) from the organization. This incompleteness of the markets does not allow the members to better manage their income over a given period and place them at the market price, taking into account the uncertainty of the events. In addition, cooperatives, as the "property" of their constituent members (and at the same time their customers), tend to offer them lower selling prices (interest rates) than would be possible. To maximize profit. In such circumstances, it is not conceivable to increase the value of the firm (valued at prices quoted by the market). Even if this is not the objective pursued by these institutions, it follows that the individual interests of the members will be poorly served because investments and investments will no longer be made according to the preferences and expectations of each member.

In microfinance, we can consider the concentration of property rights as a solution to this problem. In cooperatives and mutual tontines, members elected at general meetings are managers. As such, they hold the residual control rights and as owners of the structure set up (association or cooperative), they are claiming residual profits. Thus, the fact that these functions of managers and owners are simultaneously fulfilled by the same group of "stakeholders" ("here the owners"), the risk of expropriation (of the wealth of the owners by the managers) due to conflicts of ownership interest is mitigated, provided that this group of managers - owners - customers do not abuse their prerogatives by arrogating the maximum benefits to the detriment of the other "stakeholders". In the process, this results in a reduction in direct agency costs or transaction costs. Ultimately, "good" governance can help avoid possible inefficiencies for MFIs (regardless of their legal form).

\section{Empirical studies}

Since microfinance is supposed to adapt to the realities of the localities where it is located, their difficulties vary in their nature from one geographical area to another. Thus, MFIs can be efficient or not, given the difficulties they face. Some authors have studied the efficiency of MFIs and have come up with some interesting conclusions. We have among others Nzongang, and al. [18] who, in their study of the financial and social efficiency of micro-finance institutions of the $\mathrm{MC}^{2}$ network, find that these MFIs 
are on average globally efficient under the two assumptions of constant return on scale (CER) and Variable scale efficiency (REV). A year later, Nzongang and Kamdem [19] reach the same result in their study on the issue of the efficiency of MFIs of the same network $\left(\mathrm{MC}^{2}\right)$. From these results, we can formulate our first hypothesis as follows:

Hypothesis 1: Cameroon's micro-finance institutions would be technically efficient overall regardless of the assumed yield assumption.

Among the factors (or variables) that could hold our attention on the performance of MFIs, we have identified six variables among others that are found in the financial literature. Thus we can mention: the size, the age, the number of customers, the provisions, the geographical area and the environment. Few authors have considered Kobou, and al. [2], which shows that the efficiency of MFIs is explained by variables such as: poverty rate, lending rate, groups, environment, geographical area, number of women members and the credit rate. In the same vein, Mondjeli [3] finds as determinants of effectiveness levels the age, the number of women members of the MFI, the poverty rate, the credit interest rate, the implementation, the debtor interest rate and the region of implementation. From all these lessons, we position ourselves and formulate our second hypothesis:

Hypothesis 2: The performance of MFIs would depend on the specific environmental factors specific to them.

\section{From this second hypothesis come the following assumptions}

Hypothesis 2-1: The specific or endogenous variables (size, age, provision and number of clients) of a microfinance institution would influence its level of performance.

Hypothesis 2-2: The environmental or exogenous variables (area and setting environment) of a microfinance institution would influence its level of performance.

In view of the above, we note that Cameroon's microfinance institutions are generally performing well and that this performance would be dependent on a set of specific and environmental factors specific to the latter. We can schematize the hypotheses by the following conceptual model:

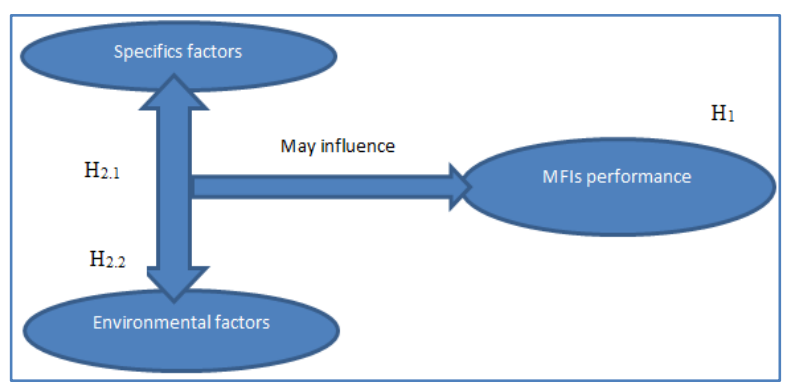

Source: Author's construction

The verification of this observation requires the monitoring of a very appropriate methodology.

\section{METHODOLOGICAL APPROACH}

The methodology used in this study consists of two parts: first, the study sample, the data source and the descriptive analysis; then in a second time, the framework and the method of analysis.

\section{The study sample, the data source and the descriptive analysis}

This research uses data from a survey of MFIs with at least five years of existence as of December 31, 2014. The quota method helped to determine the number of MFIs to investigate in each city. Microfinance institutions were selected from the list of Cameroonian MFIs published on June 30, 2012 by the Ministry of Finance. At the end of the data collection, a sample of 106 microfinance institutions was selected. The main advantage of this study is that it covers both urban and rural areas. The distribution of our sample, which follows the configuration of the Cameroonian MFIs, is represented in the following table-1:

Table-1

\begin{tabular}{|c|c|c|c|c|c|c|}
\hline \multicolumn{7}{|c|}{ Breakdown by region } \\
\hline & Center & Littoral & West & South-West & North-West & Total \\
\hline Size & 29 & 31 & 18 & 13 & 15 & 106 \\
\hline Percentage & 27.36 & 29.24 & 16.98 & 12.26 & 14.15 & 100 \\
\hline \multicolumn{7}{|c|}{ Breakdown by category } \\
\hline & \multicolumn{2}{|c|}{ Category 1} & \multicolumn{2}{|c|}{ Category 2} & \multicolumn{2}{|l|}{ Total } \\
\hline Size & \multicolumn{2}{|l|}{81} & \multicolumn{2}{|l|}{22} & \multicolumn{2}{|l|}{106} \\
\hline Percentage & \multicolumn{2}{|l|}{79.24} & \multicolumn{2}{|l|}{20.76} & \multicolumn{2}{|l|}{100} \\
\hline \multicolumn{7}{|c|}{ Breakdown by belonging } \\
\hline & \multicolumn{2}{|c|}{ Independent } & \multicolumn{2}{|c|}{ In network } & \multicolumn{2}{|l|}{ Total } \\
\hline Size & \multicolumn{2}{|l|}{60} & \multicolumn{2}{|l|}{46} & \multicolumn{2}{|l|}{106} \\
\hline Percentage & \multicolumn{2}{|l|}{56.60} & \multicolumn{2}{|l|}{43.40} & \multicolumn{2}{|l|}{100} \\
\hline
\end{tabular}

Source: Author's construction 
The data used in this research is secondary and comes from the financial statements of the different MFIs. The data collected on the variables used to calculate the performance of MFIs and its determining factors only concern the financial year 2015. We selected 106 MFIs in Cameroon with more than 5 years of operation. This selection guarantees a certain financial sustainability of the MFI as well as an effective social implantation. A summary of the data used from the 2015 financial statements is presented in Table 2.

Table-2

\begin{tabular}{|c|c|c|c|c|}
\hline & Average & Standard deviation & Minimum & Maximum \\
\hline \multicolumn{5}{|l|}{ Inputs } \\
\hline Capital (1000 CFAF) & 36710261,3 & 25263271,2 & 2277728 & 135123870 \\
\hline Work (1000 CFAF) & 7067650,28 & 8280364,23 & 2178095 & 86379125 \\
\hline Woman 1 & 523,6 & 297,86 & 102 & 1700 \\
\hline Operating load & 6030451,43 & 3666792,21 & 958610 & 18789333 \\
\hline \multicolumn{5}{|c|}{ Intermediate products } \\
\hline Other charges & 636569,217 & 797779,911 & 95610 & 7925125 \\
\hline Deposits & 137404212 & 163895299 & 10500000 & 810147100 \\
\hline Credits & 104644778 & 125040495 & 1200000 & 620147100 \\
\hline \multicolumn{5}{|l|}{ Outputs } \\
\hline Operating products & 43404371,6 & 32720007,8 & 7815125 & 171202276 \\
\hline Other products & 10646824,3 & 8444175,71 & 958555 & 50202274 \\
\hline Customer 1 & 1288,05 & 819,719167 & 253 & 4512 \\
\hline Woman 2 & 1,39047619 & 1,08390164 & 0 & 6 \\
\hline
\end{tabular}

Source: author's construction

This table shows a set of inputs and outputs whose combination in the DEAP $\left[{ }^{3}\right]$ software allows generating the performance levels of the different microfinance institutions.

\section{Environment and method of analysis}

This is to present the approach and the tools used to understand the performance levels of MFIs and identify the factors.

\section{Methodological framework for determining the performance levels of MFIs in Cameroon}

MFI performance levels are estimated using the Data Envelopment Analysis (DEA) method. Indeed, the performance of MFIs has been studied many times using this method. Two main approaches are generally used to measure the efficiency of a production unit. It is the method of productive efficiency based on the relationship between the principal and the agent and the productive efficiency method based on production frontiers. The latter approach which interests us here is subdivided into two main methods namely: the parametric method and the nonparametric method.

The parametric method requires knowing the functional form of the production function. However, the functional form of the production function of an MFI is not known at priori. Thus, we retain the DEA method insofar as it is generally recommended when the functional form of the company is not known or when the company produces several outputs.

${ }^{3}$ Data Envelopment Analysis Program
The purpose of the DEA method, based on linear programming, is to identify empirical production functions. It was developed for the first time by Charnes, and al. [20] based on the work of Farell [21]. Their approach, known as the CCR model, assumes that the production function has constant returns and opts for an inputs orientation. It has been extended by the work of Banker, et al. [22] which takes into account the variable returns to scale. The DEA method estimates the efficiency levels of a production unit from the distance function. The distance function, which establishes a relationship between observed production and optimal output [23], is defined by the following equation:

\section{$D_{0}\left(X_{v}, Y\right)=\min \left\{\lambda: \frac{y}{\lambda} \varepsilon E\left(X_{v}\right)\right\}$}

Where $D_{o}\left(X_{v}, Y\right)$ is the distance function, $X_{v}$ is the input vector and $\mathrm{y}$ is the output vector. An MFI is said to be efficient if it maximizes its output for a given level of inputs, that is, if its efficiency level is unity. In this case, the production produced is equal to the optimal production. If the efficiency level is in the range $[0,1$ [, the MFI is considered inefficient. However, an MFI with an efficiency score closer to unity is more efficient than one whose efficiency score is farther from unity.

The specification of the model requires that inputs and outputs can be selected. As a result, we have been inspired by the work of some authors such as Yaron, Gutiérrez and al. [24], Gutiérrez, and al. [25], Cornea [26], Nzongang, and al. [4]; Nzongang and 
Djontu Maurice Armand \& Nguejio Tsajio Germain., Sch J Econ Bus Manag, Feb, 2021; 8(2): 58-68

Kamdem [4] who all used the DEA method for measuring the efficiency of MFIs.
Given these previous works, we have in the table below the inputs and outputs selected for our research as well as the measurement indicators.

Table-3: Inputs and outputs retained in our research

\begin{tabular}{|l|l|l|l|}
\hline Inputs (ressources) & Measures indicators & Outputs (producuts) & Measures indicators \\
\hline Capital & Establishment fund & Credit & Credit given to clients \\
\hline Work & Personnel load & Women 2 & $\begin{array}{l}\text { Women in the board } \\
\text { of directors }\end{array}$ \\
\hline Women 2 & Women adhesion & Products & Operating products \\
\hline Loads & Operating load & & \\
\hline
\end{tabular}

Source: author's construction

This table shows that, overall, we have four inputs and three outputs that will allow us to highlight the efficiency scores.

\section{Assessing environment for evaluating determinants of MFI performance levels \\ The DEA method incorporates only} discretionary variables, that is, those that can be manipulated by the unit of production, and does not take into account environmental variables, also called non-discretionary variables [27]. However, socioeconomic differences in MFI home settings can play a central role in determining heterogeneity among MFIs and hence in MFIs' ability to collect resources and lend to the poor [2]. In part, the socio-economic and even psychological factors of MFI localities thus determine their efficiency in the fight against poverty. These factors may include, for example, variables such as population education, poverty rate, local enrollment rate, and even the dominant religion of the region. The influence of these factors on the effectiveness of MFIs needs to be examined. The efficiency level of an MFI takes values in the interval] $0 ; 1$ ], we cannot estimate this equation by Ordinary Least Squares (OLS), but by censored models such as the generalized and censored fish model or the censored Tobit model. Indeed, censored regression models are particularly recommended when the data used is censored, in other words, the values of the endogenous variable belong to a specific interval. The fish model is often recommended when the values of the dependent variable are natural numbers. On the other hand, the Tobit model is used when two conditions are met namely:

- The dependent variable is continuous in an interval;

- The probability that the dependent variable will take zero values is positive.
For the determinants of MFI efficiency, the dependent variable "level of efficiency" is continuous in the interval] $0 ; 1]$. The censored Tobit model is not appropriate because the dependent value does not accept null values [28, 29]. Similarly, the generalized fish model cannot be used because the values of the dependent variable are not natural numbers. To circumvent this difficulty, we will rather explain the inefficiency of MFIs, using the censored Tobit model, since the level of inefficiency of MFIs takes zero and positive values and is continuous in the interval $[0 ; 1[$. Indeed, the Tobit model is used when there are a large number of observations for which the value of the endogenous variable is zero, as in the case in point where the level of inefficiency of MFIs takes values in the range $[0 ; 1$ [. The dependent variable will be censored by keeping in the sample the observations for which the value of the dependent variable is zero. A censored Tobit model can therefore be used to explain the inefficiency of MFIs. Thus, if Yi represents the level of inefficiency (1- efficiency) of an MFI $i$, the model can am written as:

$$
\mathbf{Y}_{\mathbf{i}}=\mathbf{X}_{\mathbf{i}} \boldsymbol{\beta}+\mathbf{u}_{\mathbf{i}} \quad \text { where } \quad\left\{\begin{array}{c}
\mathrm{Y}_{\mathrm{i}}=\mathrm{Y}_{\mathrm{i}}^{*} \text { if } \mathrm{Y}_{\mathrm{i}}^{*}>0 \\
\mathrm{Y}_{\mathrm{i}}=0 \text { else }
\end{array}\right.
$$

In the specification (2), $\mathrm{Y}_{\mathrm{i}}$ is the dependent variable, $X_{i}$ is the vector of the explanatory variables, $\beta$ is a vector representing the parameters to be estimated, $\mathrm{Y}_{\mathrm{i}}^{*}$ is a latent variable.

Assuming that the errors are normally distributed, the above censored Tobit model estimation will go through maximizing the log likelihood that is written:

$$
\log \mathrm{L}=\sum_{\mathrm{i}=1}^{\mathrm{n}} \log \left[1-\Phi \mathrm{X}_{\mathrm{i}} \beta / \delta\right]+\sum_{\mathrm{i}=1}^{\mathrm{n}} \log \left(\frac{1}{\sqrt{2 \Pi \delta}}\right)-\frac{\sum_{\mathrm{i}=1}^{\mathrm{n}}\left(\mathrm{Y}_{\mathrm{i}} \mathrm{X}_{\mathrm{i}} \beta\right)^{2}}{2 \delta^{2}}(3)
$$

Where $\mathrm{n}$ represents the observation number and $\delta$ the standard deviation

The benchmark year for assessing the determinants of MFI performance is 2015. The variables used in this study are mixed. Nonperformance, age, board size, number of clients and risk portfolio are quantitative variables whose statistics are derived from the MFI database; while the environment and the area of implantation are qualitative variables. The dependent variable c_perf expresses the underperformance levels of each MFI obtained by making the following calculation: (1-c_perf of MFIs); performance scores were generated when estimating DEA. The zon variable takes the value 1 if the MFI is 
located in the French-speaking part of Cameroon and the value 0 otherwise. Similarly, the millet variable takes the value 1 if the MFI is located in rural areas and 0 otherwise.

\section{RESULTS AND INTERPRETATION}

The results are analyzed through performance levels and determinants of MFI performance.

\section{Performance levels}

Performance scores are generated using the DEAP software. The restitution of the results is made under the assumptions of constant returns to scale (REC) and variable returns of scale (REV). Table 4 summarizes the technical performance scores of all the MFIs in our study.

Table-4: Summary of Results DEA-Technical Performance-Model CCR and CCB-Scale

\begin{tabular}{|c|c|c|c|c|c|c|c|}
\hline & \multicolumn{2}{|l|}{ Average } & \multicolumn{2}{|c|}{ Standard deviation } & \multicolumn{2}{|c|}{ Minimum } & Maximum \\
\hline \multicolumn{8}{|c|}{ Constant Scale Efficiency - CCR Model } \\
\hline Overall & \multicolumn{2}{|c|}{0.6682} & \multicolumn{2}{|l|}{0.2364} & \multicolumn{2}{|l|}{0.17} & 1 \\
\hline \multicolumn{8}{|c|}{ Variable Scale Efficiency - BCC Model } \\
\hline Overall & \multicolumn{2}{|c|}{0.8214} & \multicolumn{2}{|l|}{0.1785} & \multicolumn{2}{|l|}{0.402} & 1 \\
\hline \multicolumn{8}{|l|}{ Scale } \\
\hline Overall & \multicolumn{2}{|l|}{0.8124} & \multicolumn{2}{|l|}{0.2014} & \multicolumn{2}{|l|}{0.17} & 1 \\
\hline \multicolumn{8}{|c|}{ Type of yield } \\
\hline & \multicolumn{2}{|c|}{ Increasing } & \multicolumn{2}{|l|}{ Constant } & \multicolumn{2}{|c|}{ Desreasing } & \\
\hline & Number & $\%$ & Number & $\%$ & Number & $\%$ & \\
\hline Overall & 75 & $70.75 \%$ & 22 & $20.76 \%$ & 9 & $8.49 \%$ & \\
\hline
\end{tabular}

Source: author's construction

Overall, performance implies for a company that the available means are best used and that the optimal productive combinations are taken [19], $\left[{ }^{4}\right]$. Overall, the MFIs in the sample have an average performance of $66.82 \%$ and $82.14 \%$ respectively when the assumptions of constant returns to scale and variable returns to scale are advanced. These scores are higher than those found by Kobou and al in 2010 on the MFIs of the CAMCCUL network $(40.10 \%$ and $57.50 \%)$ and lower than those of Nzongang and Kamdem in 2013 on the MFIs of the $\mathrm{MC}^{2}$ network $(87.55 \%$ and $91.79 \%)$. Note, however, that these average values conceal a large divergence of scores within the sample. Indeed, according to the CCR model, the lowest performance is $17 \%$ and $40.20 \%$ according to the BCC model. It should also be noted that nearly $50.94 \%$ and $54.57 \%$ of the sample MFIs respectively in REC and REV perform above the average of $66.82 \%$ in REC and $82.14 \%$ in REV.

In addition, $67.92 \%$ and $93.39 \%$ of the sample MFIs respectively in RECs and REVs performed above $50 \%$. This leads us to say that on average, all the MFIs in the sample have good results. It is also important for us to note that, overall, $19.81 \%$ (21 MFIs/106) and $30.02 \%$ (35 MFIs/106) of the MFIs in the sample achieved $100 \%$ performance over the entire period respectively under the assumption of constant returns to scale and the assumption of variable returns to scale.

\footnotetext{
${ }^{4}$ According to Nzongang (2011), efficiency methods distinguish between allocative efficiency and technical efficiency. Allocatively efficient businesses are those that choose the least expensive factor combination, and offer the most profitable product combination.
}

Regarding the types of return, Table 4 shows that $70.75 \%, 20.76 \%$ and $8.49 \%$ of MFIs evolve respectively in increasing, constant and decreasing returns to scale.

These three aspects of returns to scale can be explained as follows

- In the case of increasing returns to scale, we find that the output of 75 MFIs in our sample varies more than the variation in the factors of production used. The production of an additional unit is then accompanied by a decrease in unit cost, and the same amount of factors can produce more. In this case we speak of "economy of scale".

- $\quad$ Regarding the case of constant returns to scale, 22 MFIs in our sample have a production that varies in the same proportion as the factors of production used. The cost also remains constant.

- In the case of decreasing returns to scale, we have 9 MFIs whose production varies less than the variation in the factors of production used. This means that the marginal cost is increasing (the more we produce and the more it is expensive to produce an additional unit) or that more factors are needed to produce a unit. When returns become negative, we talk about "waste of scale" or "diseconomy of scale".

The performance scores thus obtained and analyzed, it is now time to make an evaluation of the determinants of the performance.

\section{Determinants of MFI performance}

The estimation of the determinants of the performance of the MFIs, thanks to the Stata 12 software, gives the results contained in Table 5. The 
Djontu Maurice Armand \& Nguejio Tsajio Germain., Sch J Econ Bus Manag, Feb, 2021; 8(2): 58-68

estimation model is globally significant because the

return of scale retained.

Chi2 is significant at $1 \%$ whatever the assumption of

Table-5: Outcome of Determinants of MFI Performance

\begin{tabular}{|c|c|c|c|c|c|c|}
\hline \multicolumn{7}{|c|}{$\begin{array}{l}\text { Number of obs : } 106 \\
\text { Prob> chi2: } 0.0018 \\
\text { Log likelihood: }-28.840384\end{array}$} \\
\hline \multirow{2}{*}{$\begin{array}{l}\text { c-perf } \\
\text { Tail.ca }\end{array}$} & \multirow{2}{*}{$\begin{array}{l}\text { Coef. } \\
-.0377593 *\end{array}$} & \multirow{2}{*}{$\begin{array}{l}\text { Std. Err. } \\
.013122\end{array}$} & \multirow{2}{*}{$\begin{array}{l}T \\
-2.88\end{array}$} & \multirow{2}{*}{$\begin{array}{l}P>|t| \\
0.005\end{array}$} & \multicolumn{2}{|c|}{ [95\% Conf. Interval] } \\
\hline & & & & & -.063793 & -.0117257 \\
\hline Nc & $-.3291711 * * *$ & .0000335 & -1.77 & 0.087 & -.0000542 & .0000786 \\
\hline Par.30 & $.1897199 * * *$ & .1027443 & 1.85 & 0.054 & -.1507763 & .2642162 \\
\hline zone & .2874613 & .169397 & 1.37 & 0.177 & -.1096428 & .5745654 \\
\hline Mil & $-.1883653 * * *$ & .1182661 & -1.69 & 0.089 & -.0659947 & .050478 \\
\hline Age & -.1165499 & .0912305 & -1.28 & 0.209 & -.3007935 & .0676938 \\
\hline Cons & -.3204729 & 1.338349 & -0.24 & 0.812 & -3.023323 & 2.382377 \\
\hline /sigma & .2572632 & .0371755 & & & .1821857 & .3323407 \\
\hline \multicolumn{7}{|c|}{$\begin{array}{l}\text { left-censored observations at ineff } \text { rec }<=0: 21 \\
\text { uncensored observations: } 84 \\
\text { right-censored observation at ineff } \text { rec }>=.82999998: 1\end{array}$} \\
\hline
\end{tabular}

$* * *(* *)\{*\}$ : Significant respectively at $10 \%, 5 \%, 1 \%$

Source: author's construction from stata 12

The variables that explain the performance of the MFIs are the Mil (implantation milieu); Par.30 (risk portfolio greater than 30 days); the $\mathrm{Nc}$ (number of clients) and Tail.ca (size of the board of directors).

Regarding the size variable of the board of directors (board.di), its coefficient $=-.0377593<0$ and $\mathrm{P}>|\mathrm{t}|=0.005<1 \%$ this shows that the coefficient for the board size variable (board.si) is negative and statistically significant at the $1 \%$ level. This negative sign (-) shows that the size variable of the board of directors (board. di) has a negative influence on the underperformance and thereby has a positive impact on the performance of the microfinance institutions. This result is in line with our expectations and joins those of Jebli 2012 then Kyereboah and Osei 2008. Indeed, the establishment of mechanisms of good corporate governance allows a good use of resources in Cameroonian MFIs. Thus, Cameroonian MFIs that practice good corporate governance are more likely to perform well. Good corporate governance should therefore be a major concern for the managers of Cameroonian MFIs and other stakeholders in these institutions. This would also mean that institutions with a good governance mechanism, allows a good followup of the actions of the various stakeholders and thereby also the achievement of a consistent performance.

For the variable Number of Client $(\mathrm{Nc})$, coef $=$ $-0.3291711<0$ and $\mathrm{P}>|\mathrm{t}|=0.087<10 \%$. Here we have a negative and statistically significant coefficient at the $10 \%$ level. This simply means that the Number of Clients (Nc) variable has a negative impact on the MFI's underperformance and, consequently, positively on their performance. This result is very understandable in that the main mission of MFIs is to offer financial services to the poorest. This shows that the more clients an MFI has, the more it reaches the poor and the better. This result fills our suspicions.

For the risk portfolio variable greater than 30 days (rpv.30), the coef $=+0.1897199>0$ and $\mathrm{P}>|\mathrm{t}|=$ $0.054<10 \%$. With this positive sign $(+)$, the coefficient of the rpv.30 variable is positive and statistically significant at the $10 \%$ level; which shows, moreover, that this variable has a positive influence on the underperformance and, conversely, negatively on the performance. In a company, when the risk portfolio is high, this can only be a source of weakness for it. A high-risk portfolio simply means that the ratio of at-risk debt to the gross amount of loans tends gradually to 1 . So, the higher the risk portfolio in an MFI, the lower the performance. This result thus joins that of Jebli [11].

The coefficient of the variable Milieu $($ Mil $)=-$ $0.1883653<0$ and $\mathrm{P}>|\mathrm{t}|=0.089<10 \%$. This means that the coefficient of the Middle (Mil) variable is negative and statistically significant at the $10 \%$ threshold. The negative sign (-) shows that the Middle (Mil) variable has a negative influence on the underperformance, and consequently a positive influence on the performance. Indeed, the microfinance institutions being micro-banks of development, the positive sign can be justified in our study on one hand by the fact that the majority of the MFIs of our sample $(62 \%)$ are located in urban environment and of on the other hand, nearly $82.35 \%$ of successful MFIs are located in urban areas. This result is consistent with that of Kablan [30], which shows that the setting environment should have a positive impact on performance, as MFIs operate most often in communities, taking into account the socio-cultural realities of the latter. Even though many MFIs operate in urban areas, we believe that the population targeted by it may be fundamentally, according to the literature, 
the one without access to financial services as offered by conventional banks.

\section{The other variables, namely}

- The area where the MFI is located, with a positive sign (contrary to the expected sign);

- The age of the microfinance institution, with a negative sign (same as the expected sign);

Are not statistically significant and appear as if they have no effect, neither on the performance nor on the underperformance of microfinance institutions.

Overall, we find that the performance of microfinance institutions is impacted by four variables (location, board size, number of clients, and risk portfolio) of the six suspected variables.

\section{CONCLUSION}

Produced on a large sample of microfinance institutions in Cameroon, the study evaluates, on one hand, the performance levels of these MFIs by combining both the social aspect (targeting the poor) and the financial aspect (sustainability financial). On the other hand, it analyzes the degree of involvement of certain specific and environmental factors on the level of performance of MFIs.

Analyzes show that MFIs in Cameroon are characterized by a variety of performance levels. These MFIs generally have an average technical performance level of $66.82 \%$ and $82.14 \%$ respectively when the assumptions of constant returns to scale and variable returns to scale are advanced. This leads us to say that on average, all the MFIs in the sample have good results. These results are consistent with those of Nzongang and al [18] and Nzongang and Kamdem [4]. It is also important for us to note that, overall, $19.81 \%$ (21 MFIs / 106) and 30.02\% (35 MFIs / 106) of the MFIs in the sample achieved $100 \%$ performance over the entire period, respectively under the assumption of constant returns to scale and the assumption of variable returns to scale. Note that these results conceal disparities related to either specific factors (such as board size, age, risk portfolio and number of MFI clients), and environmental factors (environment and implantation area). This is how we find in our study that the performance of MFIs is significantly influenced by some of these factors, such as the size of the board, the risk portfolio, and the number of clients and the location of the MFI. These results are consistent with those of Kablan [10] Zett [31], Mondjeli [3] and Kobou, and al. [2].

\section{REFERENCE}

1. COBAC. Enquête sur l'évolution de l'activité de la microfinance dans la CEMAC », Statistiques arrêtées au 31 décembre. 2008.
2. Kobou G, Ngoa Tabi H, Moungou S. Efficacité du financement des micro et petites entreprises dans la lutte contre la pauvreté au Cameroun. 2010.

3. Mondjeli Nwa D. Ciblage des Pauvres et Rentabilité Financière dans les Institutions de Micro-finance au Cameroun : Complémentarité ou Incompatibilité ? », Rapport de Recherche du FRCIEA. 2013. No.53/2013. Disponible sur : www.trustafrica.org/icbe

4. Nzongang J, Kamdem D. La problématique de $\mathrm{l}^{\text {ee }}$ efficience dans les institutions de microfinance (IMF): Le cas du réseau des Mutuelles Communautaires de Croissance (MC 2) au Cameroun. OCDE (2003), L entreprenariat et le développement économique local. Quels programmes et quelles politiques. 2013:901-26.

5. Cull R, Demirgu“ ç- Kunt A, Morduch J. Financial performance and outreach: A global analysis of leading microbanks. The Economic Journal. 2007 Feb 1;117(517):F107-33.

6. Wale LE. Performance analysis of a sample microfinance institutions of Ethiopia. Available at SSRN 1398167. 2009 May 2.

7. Kereta BB. Outreach and Financial Performance Analysis of Microfinance Institutions in Ethiopia ». Addis-Ababa (Éthiopie) : African Economic Conference United Nations Conference Center (UNCC). 2007; 31.

8. Hartarska V. Governance and performance of microfinance institutions in Central and Eastern Europe and the newly independent states. World development. 2005 Oct 1;33(10):1627-43.

9. Bassem BS. Efficiency of microfinance institutions in the Mediterranean: an application of DEA. Transition Studies Review. 2008 Sep 1;15(2):34354.

10. Kablan S. Mesure de la Performance des Banques dans les Pays en Développement: Le Cas de l'UEMOA (Union Economique et Monétaire Ouest Africaine). African Development Review. 2009;21(2):367-99.

11. Jebli. les déterminants de la performance des institutions de microfinance marocaines », thèse de doctorat.2012.

12. Milgrom P, Roberts J. Economics, Organization and Management, traduction française, Économie, Organisation et Management, De Boeck Université, coll. Ouvertures économiques-Balises. 1997.

13. Lobez F. le rationnement du crédit: une synthèse. Finance. 1988; 9: 2.

14. Stiglitz JE, Weiss A. Credit rationing in markets with imperfect information. The American economic review. 1981 Jun 1;71(3):393-410.

15. McKinnon R. Money and capital in economic development, the Brookings institute. Washington, DC. 1973.

16. Soulama S. Efficacité technique et inefficience à l'échelle des Institutions de Microfinance au Burkina Faso. Laboratoire d'Economie d'Orléans, UMR CNRS. 2008;6221:1-24. 
17. Labie M. Perspectives d'autonomie et de pérennisation des systèmes financiers décentralisés. Revue Tiers Monde. 1996 Jan 1:85-96.

18. Nzongang J, Kamdjoug JK, Piot-Lepetit I, Omenguele GR, Nishimikijimana E. Efficience technique des IMF du réseau des Mutuelles Communautaires de Croissance (MC2) au Cameroun. Revue Sciences de Gestion. 2010(77):93-110.

19. Nzongang J. La mesure de la performance des établissements de microfinance (EMF) au Cameroun. La revue des Sciences de Gestion. 2011(3):139-46.

20. Charnes A, Cooper WW, Rhodes E. Measuring the efficiency of decision making units. European journal of operational research. 1978 Nov $1 ; 2(6): 429-44$.

21. Farrel J. The measurement of Productive efficiency. Journal of the Royal Statistical Society. Series A, General 125. Part. 1957(2):252.

22. Banker RD, Charnes A, Cooper WW. Some models for estimating technical and scale inefficiencies in data envelopment analysis. Management science. 1984 Sep;30(9):1078-92.

23. Shephard RJ. Computer programs for solution of the Astrand nomogram and the calculation of body surface area. The Journal of sports medicine and physical fitness. 1970 Dec;10(4):206-10.

24. Yaron J. Successful Rural Finance Institutions: World Bank Discussion Papers 150. The World Bank, Washington DC.
25. Gutiérrez-Nieto B, Serrano-Cinca C, Mar Molinero C. Social efficiency in microfinance institutions. Journal of the operational research society. 2009 Jan 1;60(1):104-19.

26. Cornée S, THENET G. Analyse de la convergence entre performances financières et performances sociales: application de la méthode Data Envelopment Analysis sur 18 institutions de microfinance péruviennes. Centre de recherche en économie et Management. 2006:101.

27. Afonso A, Aubyn MS. Cross-country efficiency of secondary education provision: A semi-parametric analysis with non-discretionary inputs. Economic modelling. 2006 May 1;23(3):476-91.

28. Maddala GS. Limited-dependent and qualitative variables in econometrics. Cambridge university press; 1986 Jun 27.

29. Greene M. Releasing the imagination: Essays on education, the arts, and social change. Jossey-Bass; 1995.

30. Kablan, S. Efficacité des Institutions de Microfinance en UEMOA: une approche OutreachIntermédiation Financière », halshs-00710206, version 1-20 june. 2012.

31. Zett JB. «Croissance, efficacité et taille des Institutions de Microfinance (IMF) », Université de Ouagadougou. Laboratoire d'Economie Publique, Sociale et Solidaire.2009. 